\title{
Tripled coincidence theorems for monotone mappings in partially ordered metric spaces
}

\section{MARIN BORCUT}

\section{ABSTRACT.}

In this paper, we establish tripled coincidence point theorems for a pair of mappings $F: X \times X \times X \rightarrow X$ and $g: X \rightarrow X$ satisfying a nonlinear contractive condition ordered metric spaces. Presented theorems extend several existing results in the literature: [Borcut, M. and Berinde, V., Tripled coincidente point theorems for contractive type mappings in partially ordered metric spaces, Aplied Mathematics and Computation, 218 (2012), No. 10,5929-5936], and Berinde, Borcut in article [Berinde, V., Borcut, M., Tripled fixed point theorems for contractive type mappings in partially ordered metric spaces, Nonlinear Anal., 74 (2011), 4889-4897].

DePartMent of MATHEMATics AND COMPUTER SCIENCE

NORTH UNIVERSITY OF BAIA MARE

VICTORIEI 76, 430122 BAIA MARE, ROMANIA

E-mail address: marinborcut@yahoo.com 